Citation information: Meghani, Z. (2014). Risk Assessment of Genetically Modified Food and Neoliberalism: An Argument for Democratizing the Regulatory Review Protocol of the Food and Drug Administration. Journal of Agricultural and Environmental Ethics, 27(6), 967-989.

\title{
RISK ASSESSMENT OF GENETICALLY MODIFIED FOOD AND NEOLIBERALISM: AN ARGUMENT FOR DEMOCRATIZING THE REGULATORY REVIEW PROTOCOL OF THE FOOD AND DRUG ADMINISTRATION ${ }^{1}$
}

\section{Introduction}

The US Food and Drug Administration's regulatory review of genetically modified (GM) ${ }^{2}$ food (both the plant and the animal variety) is influenced by neoliberalism. This paper argues that the risk assessment of new GM food should be democratized to counteract that bias. It is proposed that the public constituencies that could be affected by a new GM food should decide any normative questions that are entailed by the regulatory review of that entity. While ethical and political reasons have been articulated for substantive public engagement in the risk assessment of GM food, this paper makes a different kind of case for it. It provides an original epistemic argument for a revised regulatory review process for GM food that is inclusive and unbiased.

There are multiple ethical reasons for substantive involvement of the public in risk regulation. One of the key ethical justifications is that the imposition of risk on individuals requires that they consent to it (Myhr \& Traavik 2003, p.242; Jensen 2006). Another reason is that if the risk regulation process is closed and opaque, individuals cannot get the information they need to make informed decisions. In other words, their ability to act autonomously is undermined (Johnson 2007). Third, the proprietary interests of the company sponsoring a GM food may be in conflict with those of certain public constituencies, thus, they should be part of the risk regulation decision-making process (Myhr \& Traavik 2003, p.243). For instance, one such group could be an organization that represents the concerns of farm workers who are exposed to a pesticide used on GM plants that might be neurotoxic to humans (Cattani et al. 2014; Guia 2012). Fourth, industry scientists involved in the development of a biotechnology could be biased towards their funders' interests (Myhr \& Traavik 2003, p.241). So, public involvement in the regulatory process would correct for that partiality. A fifth and related reason is that individual biotechnology companies and the industry as a whole may focus primarily or solely on the benefits of the products rather than being appropriately attentive to their adverse impact (Myhr \& Traavik 2003, p.241). Therefore, public participation in the regulatory process could ensure that possible harms from the biotechnology are not minimized or overlooked in the

\footnotetext{
${ }^{1}$ This paper draws on and builds on earlier papers, especially Meghani \& Kuzma (2011), Meghani (2009), and Meghani \& de Melo-Martín (2009).

2 The terms "genetically modified (GM)" and "genetically engineered (GE)" are used interchangeably in this paper. They denote entities whose genetic material has been changed by means of "in vitro nucleic acid techniques, including recombinant deoxyribonucleic acid (DNA) and direct injection of nucleic acid into cells or organelles" (WHO 2008, p.2).
} 
review and decision-making process. Sixth, as the risk policies may have an impact on future generations, they must be ethically justified (Johnson 2007). Seventh, approval of the use of GM crops may enhance the monopoly of some multinational agro-chemicals corporations (Jensen 2006, 279; Madsen \& Sandoe 2001, 164), driving organic or small scale farmers out of business. Public involvement in the regulatory process might slow or counteract that eventuality.

There are also political reasons justifying public engagement in the regulatory review process for GM food. In a democracy, the people have the right to be autonomous. If those who are affected by GM food do not have a seat at the risk regulations table, they are denied the opportunity to be self-determining (Meghani 2009). Another political reason for public involvement is that government policies and regulations about biotechnology might be more easily accepted by the polity if it is part of the decision-making process rather than marginalized or excluded from it. There might also be increased trust in policies and regulations governing GM food if there is substantive public participation in the review process (Myhr \& Traavik 2003, p.243, Murphy-Lawless 2004, p.397).

Aside from ethical and political reasons, there are epistemic arguments for public involvement in the regulatory process. One of those arguments is that non-scientists who have unique insight about the phenomenon under review that is based on their daily, close acquaintance with it in the real world (i.e., non-laboratory) context should be involved in its risk regulation. Their knowledge of the phenomenon (i.e., how it functions under particular circumstances) is different from the theoretical, laboratory based, or bureaucratic understanding of it possessed by scientific and government experts, respectively (Wynne 1989, pp. 14-5, 33-8). Thus, this sub-group of laypersons is able to make a unique epistemic contribution in the risk regulatory process.

Another epistemic argument justifying layperson involvement in the decision-making process about new technologies, including, presumably, their risk regulation, is as follows: Laypersons should be involved in decision-making about new technologies because they can serve an indirect epistemic function by challenging their developers to create innovative entities and processes (Jasanoff 2003, p.237). This argument conceptualizes laypersons as epistemic catalysts of sorts that motivate those who create new technologies. It does not recognize laypersons themselves as epistemic agents.

This essay offers a different epistemic argument for layperson engagement in decisionmaking about technologies, but it limits itself to the risk regulation of GM food. It is argued here that laypersons can serve as epistemic agents during the risk assessment of GM foods. They have knowledge of the values, concerns, and interests of the informal epistemic communities to which they belong, and if a new GM food has the potential to affect those groups, then, in a democracy, the layperson representatives of those communities should have the opportunity to decide the normative issues that arise during its regulatory review.

Making this epistemic argument means challenging the FDA's claim that its regulatory review of GM food is a purely scientific activity that is untainted by any normative considerations, including ethical or political values. After all, the agency's commitment to that notion motivates its refusal to engage with public constituencies on normative issues about GM food. Thus, this paper begins by providing evidence that the FDA's regulatory decisions about GM foods are shaped by a commitment to neoliberal values, which are in tension with its primary mission of protecting public health. The influence of neoliberalism on the agency's GM food policy is discussed at length. In addition, the FDA's risk assessment of a GM salmon is used as a case study to analyze and critique the impact of the ideology on its regulatory review. 
Then, it is shown that the FDA's stance that risk evaluations are and should be value-neutral endeavors is not warranted. It is also argued that the agency is not justified in marginalizing laypersons in the regulatory review process. Following that, the case is made that given that risk assessments involve value judgments, in a democracy, the polity should have the opportunity to make the normative decisions entailed by the regulatory review of new GM foods.

\section{Neoliberalism and the US Food and Drug Administration's Policy Stance on Genetically Modified Food and Genetically Engineered Animals}

The Food and Drug Administration (FDA) identifies its primary mission as protecting public health by ensuring the safety of food additives and commercial foods, including GM foods (FDA 2012. About FDA $){ }^{3}$ Historically, the public policy decisions of regulatory agencies were made on utilitarian grounds, with the aim of maximizing social benefits at the lowest cost (Guehlstorf 2004, p.49). This paper contends that since the 1980s, the FDA's regulatory review of GM food has been significantly shaped by a neoliberal agenda even though the agency has not acknowledged it.

Neoliberalism is a theory of political-economic practices (Harvey 2005, p.2). Proponents of the ideology contend that human well-being is best served if the state fosters private enterprise (Harvey 2005, p.2). The larger aim is to enhance the role of the private sector in the economy, while drastically reducing that of the public sector, with the ostensive aim of fostering individual well-being (Harvey 2005, p.33). However, in a global economy dominated by corporations, neoliberalism primarily serves the interest of those entities and the class that either owns or manages them. For instance, this can be seen by examining the ever widening gap in wealth in the US between the wealthiest class and the working class that is traceable to the adoption of neoliberal policies in the 1980s (see Domhoff 2013, especially tables 2, 5, and 6). It is also evidence of neoliberalism's tendency to favor the former group over the latter one (see Domhoff 2013, especially tables 7, 9 and 10)).

The key tenets of neoliberalism are open markets, privatization, and deregulation (Harvey 2005). Neoliberal de-regulation is generally understood to be regulatory roll-back (i.e., the state lessening or eliminating regulations in the interest of allowing market forces free reign), but there is more to it than that. Neoliberal de-regulation occurs in two phases, with the roll-back stage preceding the roll-out phase (Tickell and Peck 2002, p.384). The former stage entails the reduction or elimination of policies (such as Keynsian-welfarist policies) that are inimical to neoliberal values and interests, while in the latter phase, policies are introduced that advance neoliberal goals (read: corporate aims).

The US began its transformation into a neoliberal state in the 1980s (Harvey 2005) and its regulatory policies governing GM food and GE animals reflect the influence of that ideology.

\footnotetext{
${ }^{3}$ While poultry and meat are the purview of the US Department of Agriculture (USDA), the FDA is expected to closely coordinate with it on food safety issues about those foods. The FDA is also obligated to work with the U.S. Environmental Protection Agency (EPA), which regulates pesticides and establishes pesticide residues limits for food.
} 
Below, the following two key policy documents are analyzed, exposing their neoliberal underpinnings: ${ }^{4}$

i. The Coordinated Framework on the Regulation of Biotechnology

ii. Guidance for Industry Regulation of Genetically Engineered Animals Containing Heritable Recombinant DNA Constructs Final Guidance

Neoliberalism and the "Coordinated Framework on the Regulation of Biotechnology"

With the election of President Reagan in 1980, the White House administration issued Executive Order \#12291, which subjected to review all old and new regulations to determine their impact on the economy (EO\# 12291, Federal Register). The aim was to reduce or eliminate federal government regulations and allow industries to regulate themselves, with the end of fostering economic growth. There was no discussion of the possible impact of the de-regulation on public health and safety.

In the 1982 "Message to the Congress Transmitting the Annual Economic Report of the President," Reagan reiterated his stance on federal regulations. He stated that as part of his administration's long term economic program it would reduce the role of the federal government in the economy, including "substantial reform of Federal regulation, eliminating it where possible and simplifying it where appropriate" (Reagan, 1982). In the section of the speech that was devoted to regulatory reform, President Reagan explained that "raising productivity and reducing costs" was the overriding justification for the curtailment, if not elimination, of government regulatory oversight. The possible effect on public health and safety of the decision to reduce or eliminate regulatory oversight was not mentioned in the President's speech.

The Reagan administration's position on regulation of biotechnology was part and parcel of its larger position on federal regulations. The 1981 testimony of George A. Keyworth (President Reagan's Chief Science Advisor and Director of the US Office of Science and Technology Policy (OSTP)) before the House Committee on Science and Technology is revealing. Articulating the key tenets of neoliberal political philosophy of individual responsibility and minimal government that favored corporate self-regulation, Keysworth stated,

[“T] oday's federal role in science and technology must be different from that which has prevailed since World War II. ... [It must be] appropriate to a national mood which calls for increased vigor and acceptance of responsibility by individuals and organizations in the private sector and decreased involvement by the federal government in many of our affairs" (US Congress, House of Representatives, Committee on Science and Technology, 1982, p.14, 15).

In 1986, the OSTP issued the key regulatory policy stance document - the Coordinated Framework on the Regulation of Biotechnology (CFRB). ${ }^{5}$ It was the US' first defining

\footnotetext{
${ }^{4}$ Another significant regulatory document with a distinct neoliberal orientation is the 1991 "Report on National Biotechnology Policy" published by the President's Council on Competitiveness (see page 11). However, scrutinizing it lies beyond the scope of this essay.
} 
regulatory document about GM food. ${ }^{6}$ The CFRB held that GM food should be treated the same as their non-GM counterparts. Ostensibly, the policy stance was justified on nationalist grounds. The Reagan administration claimed that the policy would enable the nation to globally dominate the development of and trade in the new food biotechnology (FR 49: 31 Dec 1984; Levidow et al. 2007, p. 34; Rollin 1995, pp. 99-100). It also attempted to justify its decision on the grounds that it would be irrational and unscientific for the FDA to differentiate between GM food and their conventional counterparts on the basis of the process of manufacture. It contended that "[r]egulation by the FDA must be based on the rational and scientific evaluation of products, and not on a priori assumptions about certain processes" (FR 49, p. 50880).

The CFRB marked the beginning of the neoliberal de-regulatory roll-out policy phase with respect to the biotechnology industry. ${ }^{7}$ It crafted a regulatory environment that made it easy for GM food sponsors to bring their products to the market by doing four things. First, it contended that the risks associated with GM organisms were not of a different kind than those associated with non-GM entities and it held that the process of production should not matter, only the end result. Second, it stipulated that GM food were to be governed by the same laws and regulations as those that applied to non-biotech food (FR 49: 31 Dec 1984, p.50878). Thus, even today the developers of GM food do not have to meet any additional or different regulatory requirements before they sell their product in the marketplace (Millstone et al. 1999). Third, it did not require that GM products carry a label identifying and differentiating them from non-GM food. That made it easy for the producers of GM food to sell them in the marketplace. Fourth, it asserted that GM foods do not have to be identical to non-GM foods (Millstone et al. 1999, p. 525); they only have to be substantially equivalent in terms of their chemical composition to their non-GM counterparts (Levidow et al. 2007, p.34). ${ }^{8}$

While the "substantial equivalence" standard was presented by the FDA as a scientific standard, it was actually the product of political and economic considerations. It aimed to facilitate the rapid entry of the food biotechnology into the marketplace (Millstone et al. 1999, p.526). It is because the FDA construed GM food to be the same as their conventional counterparts rather than as a novel chemical compound (such as a pharmaceutical, pesticide or a pesticide), the sponsors of the food biotechnology did not have to perform time consuming, difficult to interpret, expensive toxicological tests on the basis of which the acceptable daily intake (ADI) of the novel food product would have been determined (Millstone et al. 1999, p.525). The ADI standard would have effectively limited the sale potential of GM food; the FDA

\footnotetext{
${ }^{5}$ For a detailed account of the Reagan White House's commitment to neoliberalism, particularly the reduction of regulatory oversight on corporations with the end of fostering business interests, see Jones 1999, pp.225-271, also see Sheingate 2006.

${ }^{6}$ An earlier version of the document was published in the December 31, 1984 edition of the Federal Register (FR 49, p.50856)

${ }^{7}$ The GM food was a new class of entity; there were no existing regulations that governed it. So, there was no rollback phase of de-regulation.

${ }^{8}$ In instances when similarity could not be assured by means of chemical composition tests, "feeding studies or other toxicological research could be required" (Levidow et al. 2007, p.35). The FDA does have the authority to take action against a GM food if there is evidence that it poses a demonstrable safety risk in a post-market environment (http://www.fda.gov/newsevents/testimony/ucm115032.htm). However, as there is no monitoring or tracking of GE food in the US marketplace, it is unlikely that long term post-consumption impacts will be recognized. I owe this point to J. Kuzma.
} 
mandates that the ADI of any novel chemical compound may not exceed more than $1 \%$ of the human diet (Millstone et al. 1999, p.525).

The agency also did not require that the sponsors of new food biotechnologies obtain premarket approval from it. The developers of a new GM food could, if they chose, submit to the FDA safety data from the tests they conducted on the food biotechnology. The agency did stipulate that the data provided to it ought to have enough information for its reviewers to grasp the approach used by the company. The agency lists the following as examples of the information that ought to be part of the submission:

a. "Name of the food and the crop from which it is derived;

b. $\quad$ The uses of the food, including both human food and animal feed uses;

c. The sources, identities, and functions of introduced genetic material;

d. The purpose or intended technical effect of the modification and its expected effect on the composition or characteristic properties of the food or feed;

e. The identity and function of any new products encoded by the introduced genetic material, including an estimate of its concentration;

f. Comparison of the composition or characteristics of the bioengineered food to that of food derived from the parental variety or other commonly consumed varieties with special emphasis on important nutrients, anti-nutrients, and toxicants that occur naturally in the food; g. Information on whether the genetic modification altered the potential for the bioengineered food to induce an allergic response; and,

h. Other information relevant to the safety and nutritional assessment of the bioengineered food" (US FDA. Statement of James H. Maryanski ...)

Crucially, the FDA left the design of nutrition and safety studies to the developers of new GM food (more on this later). All in all, the CFRB gave significant license to sponsors of GM food, reflecting the influence of neoliberalism on the agency.

Neoliberalism and the "Guidance for Industry Regulation of Genetically Engineered Animals Containing Heritable Recombinant DNA Constructs Final Guidance”

While the CFRB (that was issued in 1986) applies to all GM food, in January 2009, the FDA issued a new policy document that laid out its regulatory policy for GE animals. The document is the "Guidance for Industry Regulation of Genetically Engineered Animals Containing Heritable Recombinant DNA Constructs Final Guidance"" (henceforth referred to as Guidance). This FDA policy document, like the CFRB, is an instance of a neoliberal roll-out regulation; it introduces regulation that advances the interests of the nascent GE animals industry by making it fairly easy to bring GE entities to the market.

The Guidance categorizes GE animals as new animal drugs (more on that later) and as a GM food (p.23-4). This dual classification of GE animal is problematic. While the FDA sets stringent acceptable level of daily intake for pharmaceutical products, the recommendations for daily food consumption made by the US Department of Agriculture are much more relaxed (USDA, USDA MyPlate ...). Presumably, to give credibility to the food safety standard that the FDA planned to use to evaluate GE animals as GM food, the Guidance notes that it will use the

\footnotetext{
${ }^{9}$ Guidance documents issued by federal agencies do not have the force of law (Transcript, p.15).
} 
standard established by the Codex Alimentarius of the World Health Organization (WHO): "The information needed to establish food safety for food from GE animals under an NADA is consistent with that described in the Codex Guideline" ${ }^{10}$ (Guidance, p. 26). ${ }^{11}$ In terms of safety standard, the WHO's 2008 “Guideline for the Conduct of Food Safety Assessment of Foods Derived from Recombinant-DNA Animals" (like the FDA's CFRB) posits the conventional counterpart of the GE entity as the safety paradigm, requiring that GE entity be substantially equivalent in terms of composition and key nutrients to its non-GE counterpart. ${ }^{12}$ (It should be noted that the FDA's Guidance (2009) does not use the term "substantially equivalent" but it describes that standard and refers to the WHO's Guidance 2008, which uses that term). The standard of substantial equivalence, as discussed earlier, privileges the interests of the food biotechnology industry. The developers of GE animals do not have to provide evidence to the FDA that those entities qua food are identical to their non-GE counterpart. Rather they only have to show that they are substantially equivalent. That gives them considerable leeway, especially since few foods have been subject to risk assessments that fully identify all associated risks. ${ }^{13}$ Thus, the requirement that GM foods be substantially equivalent to their conventional counterpart is not a meaningful, let alone a rigorous, safety standard for the new food products.

The FDA's Guidance also treats GE animals as new animal drugs. ${ }^{14}$ The FDA claimed that it decided to construe GE animals as a drug because the rDNA construct introduced in the animals is meant to impact their bodily structure or function and the Federal Food, Drug and Cosmetic Act (FFDCA) categorizes as a drug any non-food article that aims "to affect the structure or any function of the body of man or other animals" (21 U.S. Code 321, section 201(g)). This logic, however, ignores the relevant differences between pharmaceutical products for animals, such as vaccines or antibiotics, and GM animals. The former class of entities cannot engage in the kinds of activities that a GM animal can by virtue of being an animal (Hoffman 2011).

The FDA considered GE animals to be new animal drugs because the composition of GE animals qua pharmaceutical products is not recognized by the relevant scientific experts as "safe and effective for use under the conditions prescribed, recommended, or suggested in the labeling" (21 U.S. Code 321, section 201(g)) (FDA. Importation ...). Thus, with some exception, GE animals qua new animal drug have to receive premarket approval from the agency. ${ }^{15}$ The

\footnotetext{
10 This use of the WHO's 2008 Codex guidance statement to establish the credibility of the FDA's standard amounts to circular reasoning because the FDA was involved in establishing the WHO's Codex GM food safety standard (Guidance 2009, p.24). The FDA's Guidance acknowledges that fact.

11 The WHO Guideline does not construe GE animals as animal drugs.

12 The Guideline construes the substantial equivalence criterion to be the starting point for evaluating "the safety of any identified differences (between the genetically modified food and its non-GM counterpart) so that the safety of the new product can be considered relative to its conventional counterpart" (WHO. 2008, p.3). It cautions that that the safety assessment based on the substantial equivalence standard should not be understood to "imply absolute safety of the new product" (WHO 2008, p.3).

13 The WHO's Guideline (2008) claims that whole food risk evaluations of GE animals are not performed because, first, few foods (GE or non-GE) have been subject to risk assessment that wholly identify all associated risks, second, upon risk evaluation a number of foods (which, presumably, are generally recognized as safe by the relevant experts would be found to contain elements that are harmful. (I wish to thank J. Kuzma for bringing this issue to my attention.)

${ }^{14}$ Guidance 2009, p.5-6.

${ }^{15}$ Guidance 2009, p.7.
} 
developers of GE animals must file a New Animal Drug Application (NADA) with the FDA's Center for Veterinary Medicine (CVM) ${ }^{16}$ The agency regards the rDNA construct at a particular location in the genome to be the subject of the NADA (Guidance 2009, p.6). In other words, it regulates that article in the GE animal, not the GE animal as a whole. But for the sake of linguistic convenience, the agency "refer(s) to regulation of the article (i.e., the rDNA construct) in such GE animals as regulation of the GE animal" (Guidance 2009, p.7).

The classification of GE animals as a new animal drug is problematic. Members of the National Research Council (NRC 2002) and environmental and consumer advocacy groups (Goldburg 2002; UCS 2001) have noted that it was not Congress' intent for the New Animal Drug regulations to be employed to assess the risks from GM animals when it passed the FFDCA (Logar and Pollock 2005, p.19). Logar and Pollack have argued that while the 1969 National Environmental Policy Act entails that the FDA require for any new animal drug an Environmental Assessment Statement (EAS) or the more detailed Environmental Impact Statement (EIS), the definition of "safety" in the FFDCA is unclear and it does not provide the FDA with directions for addressing environmental health concerns nor does it specify the level of environmental risk that is safe $(2005, \mathrm{p} .20)$. They have also made the case that while the FDA understands that it has a duty to consider the impact of the GM animal qua new animal drug on the entire ecosystem (CEQ/OSTP, 2001), NADAs are usually not evaluated in that way. Moreover, since the FDA's interpretation is not backed by Congress or any laws, there is no guarantee that it could not be changed overnight (Logar and Pollack 2005, p.20).

In a significant concession to industry interests, the FDA (along with other regulatory agencies) permits sponsors of new pharmaceutical products to withhold information about the creation, preparation, compounding or processing of the new biotechnology that they consider to be confidential business information (CBI). Companies claim that the public dissemination of such information would give their competitors an unfair advantage (US DHHS, USDA, US EPA. Memorandum ...). Both the FFDCA and the Trade Secrets Act bar public dissemination of "any information that is acquired as part of the new animal drug approval process and that is entitled to protection as a trade secret (21 U.S.C. § 331(j), 18 U.S.C. § 1905)... Moreover, [u]nder FDA's current regulations ... no data or information contained in ... [a] NADA are available for public disclosure before an approval has been published in the Federal Register (21 C.F.R. 514.11(d))" (Office of Science ...). The agency's Task Force on Trade Secrets justifies its stance on the grounds "that trade secrets have limited value for public disclosure, and that the value for public disclosure of other types of data, such as clinical trial results and adverse event reports, is significantly greater" (FDA. About FDA: Trade Secrets...). Thus, when a GE animal developer provides safety data to the FDA, the agency will review it and prepare a draft report that does not include information that the company deems trade secret. The FDA may not even reveal that a NADA has been filed with it. For instance, Aqua Bounty Technologies, the developer of a GM salmon, had no obligation to disclose that it filed a NADA for the fish, let alone make public the data it submitted to the FDA. ${ }^{17}$ It is because of these policies that crucial information about new GM animals is beyond the reach of public interests groups that want to investigate those animals' impact on human health or the environment.

It has been argued that neoliberal concerns have shaped the FDA's two key regulatory policies for GM food (including GM animals). Those values also pervade the agency's first

\footnotetext{
${ }^{16}$ Guidance 2009, p.4.

17 The company voluntarily disclosed it had filed a NADA but that application (with the safety data) was not available for public scrutiny.
} 
regulatory review of a GE animal, the AquAdvantage salmon, which is to be used as food. The fish is the first GM animal that the FDA is in the process of reviewing using the policy framework of the Guidance. Below, the agency's review of that GE organism is analyzed to highlight the influence of neoliberalism.

Case Study: The FDA's review of the AquAdvantage Salmon

\section{The AquAdvantage salmon}

Norway and Chile are the major producers of aquacultured salmon, with the former producing 33 percent and the latter 31 percent of the global supply of farmed salmon; other European nations supply 19 percent of the world's aquacultured salmon (FAO 2008, p.21). The fish takes thirty six months to grow to market size; during the winter months it does not grow. Aqua Bounty Technologies has developed a GM Atlantic salmon that grows even during the colder months, reaching market size in sixteen to eighteen months. The fish, because of its fast growth rate, is expected to substantially increase the profits of those who farm it. Given the GM salmon's fast growth rate (and thus shorter time to market from aquaculture facility) as well as 10-20 percent "improvement in feed conversion ratio," aquaculturists believe it will be profitable for them to raise it (Transcript 2010, p. 70). Whether that belief is justified is unclear because consumer acceptance of the fish is not guaranteed and may vary geographically and might be a function of the price of the product (Menozzi, Mora, and Merigo 2012).

To create the GE salmon, Aqua Bounty Technologies inserted a genetic on-switch from the ocean pout into the growth hormone gene from Chinook salmon. Then, it introduced the modified growth hormone gene into the Atlantic salmon, which resulted in the fish growing year round (Pollack, 2010). The GM fish is the "triploid hemizygous, all female Atlantic salmon, which bears a single copy of the stably integrated $\alpha$-form of opAFP-GHc 2 at the $\alpha$-locus in the EO-1 $\alpha$ line" (Aqua Bounty Technologies. 2010. Environmental Assessment ..., p.1). Aqua Bounty Technologies plans to sell the eyed-eggs of the GE fish for grow-out only in physicallycontained fresh water aquaculture facilities that have been approved by the FDA (US FDA. Briefing Packet ..., p.8).

The FDA's Center for Veterinary Medicine's review protocol for the NADA submitted by Aqua Bounty Technologies for its GM salmon

As discussed earlier, GE animals are classified by the FDA as a new animal drug (NAD). As a rule, new animal drug applications (NADA) are reviewed by the FDA's Center for Veterinary Medicine (CVM). It is because the FDA construed GE animals as a NAD that the CVM had the responsibility of assessing the NADA for the AquAdvantage salmon.

Assessing a NADA for a GE animal that was to be used as food was new territory for the CVM (Transcript 2010, p.11). Thus, when Aqua Bounty Technologies submitted a NADA for its GE salmon, the Center assembled a team of its experts to analyze the data. Depending on their area of expertise, the CVM reviewers (working in teams of two or more) were responsible for conducting an in-depth analysis on the relevant dataset (Transcript 2010, p.132). For instance, 
Dr. Kevin Greenlees, a toxicologist and physiologist, and Dr. Kathleen Jones, an immunologist and molecular biologist, were responsible for scrutinizing the food/feed safety data on the AquAdvantage salmon (Transcript 2010, p.198, 206), while the environmental reviewers were Dr. Eric Silberhorn, an environmental scientist with training in fish biology, toxicology, and ecological risk assessment, and Dr. Don Prater, an expert in veterinary medicine, and Dr. Barry Hooberman, a toxicology and an environmental and industrial health expert (FoodRisk.org. Biographies).

The specialist reviewers presented their analysis of the data to the larger CVM review panel. If any of the panel members had questions that could not be addressed by additional analyses, the CVM would contact Aqua Bounty Technologies for more data (Transcript 2010, p. 132).

After the CVM completed its review of the NADA submitted by Aqua Bounty Technologies for the AquAdvantage salmon, on 19-20 September 2010, the FDA held a public meeting. The goal was to allow the Veterinary Medicine Advisory Committee (VMAC) to examine the CVM's review of the AquAdvantage salmon application in a forum open to the public.

The VMAC was an independent advisory board ${ }^{18}$ comprising primarily of a variety of scientific experts, one of whom was a "technically qualified member, selected by the Commissioner or designee, who is identified with consumer interests and is recommended by either a consortium of consumer-oriented organizations or other interested persons" (FDA. Charter of the Veterinary ...). The committee also included an industry representative. The members of the Committee were considered Special Government Employees who were compensated for the cost of attending the meeting and received a per diem (FDA. Charter of the Veterinary ...). In other words, the VMAC members were not FDA employees, while the CVM reviewers were agency personnel. The scientific experts had a vote; the industry representative was a non-voting member of the advisory committee (FDA. Charter of the Veterinary ...). The recommendations of the Committee were not binding on the FDA; it was at the agency's discretion to accept or reject them. In the case of the AquAdvantage salmon, the VMAC made its recommendation but it was the FDA's decision whether or not to approve the GM fish (Transcript 2010, p. 334-5). The FDA also scheduled a short period of time for public comments on the second day of the two day meeting. Members of the public who wished to comment had to pre-register. Registrants included representatives of environmental, animal well-being, food safety, and industry groups. Each registrant was allotted five minutes of speaking time in a two day long meeting.

The Veterinary Medicine Advisory Committee's assessment of the Center for Veterinary Medicine's review of the AquAdvantage salmon NADA

Prior to the meeting, the FDA's CVM provided the members of the VMAC with a briefing packet about its risk assessment of Aqua Bounty Technologies' GE salmon. It included the NADA submitted by Aqua Bounty Technologies to the CVM. It also contained the CVM's assessment of the application for the AquAvantage salmon (FDA. Briefing Packet, p.ii).

${ }^{18}$ The FDA terminated the VMAC on September 24, 2013 (FDA. Advisory Committees ...). 
At the September 2010 public meeting with the VMAC, the CVM reviewers detailed their analysis of the data on the AquAdvantage salmon that was submitted by Aqua Bounty Technologies. They also presented the results of their safety evaluation of the new entity based on that data.

The following was the conclusion of the CVM's environmental review:

...[U]nder those conditions of use and based on all the available information that we have, we believe that the AquAdvantage Salmon are not expected to have a significant effect on the quality of the human environment including the United States, foreign nations not participating in this action, and on the global commons. ${ }^{19}$ In addition we believe that there are no effects expected on stocks of Atlantic salmon (Transcript 2010, p.250-1).

The CVM offered the following assessment of the food/feed safety of the GE salmon to the VMAC:

In conclusion, all of the data and information that we reviewed as part of this food safety assessment in addition to all the data and information that formed the previous reviews of the previous steps of this hierarchical weight of evidence approach, really drive us to the conclusion that AquAdvantage Salmon is Atlantic salmon and food from AquAdvantage Salmon is as safe as food from other Atlantic salmon (Transcript 2010, p.213).

During and following the CVM's reviewers' presentation, the VMAC members identified a variety of serious problems with the data submitted by Aqua Bounty Technologies. The GM fish's sponsor's study designs and conclusions were critiqued as well. Some of the VMAC members expressed concerns about the selective culling of fish by Aqua Bounty Technologies as it raised questions about the reliability of the data on the safety of the AquAdvantage salmon. One VMAC member noted that the CVM's own briefing package stated that the "culling procedures at the PEI (Prince Edward Island) facility are not likely representative of those used in commercial production and grow-out settings. Consequently there is some uncertainty regarding the likelihood or incidence of abnormalities in AquAdvantage salmon under commercial rearing conditions" (Transcript 2010, p.340). In the VMAC summation, a committee member stated that Aqua Bounty Technologies' study design, sample sizes, and samples did not appropriately represent the GE fish that was the subject of review (Transcript 2010, p. 341, 352). Not all of the data that Aqua Bounty Technologies submitted as part of its NADA for the triploid AquAdvantage salmon was for that fish; some of the data was for a diploid GM salmon. ${ }^{20}$

The VMAC also criticized the CVM's review of the AquAdvantage salmon NADA. Some VMAC members noted that although Aqua Bounty Technologies had not provided CVM reviewers with all of the data for the GE salmon, the CVM reviewers did not request the missing data from Aqua Bounty Technologies (Transcript 2010, p.179). In addition, the VMAC took the

\footnotetext{
${ }^{19}$ Under Executive Order 12114, the environmental assessment would have to include effects on nations that were not involved in the action but could be impacted by it (in the case of the salmon, those countries are Canada and Panama because that is where the Aqua Bounty Technologies' sites for growing the GE salmon and harvesting their eggs are located) and the global commons (Transcript (2010), p.236).

${ }^{20}$ Whether the difference between the fish is significant is unclear; it was not discussed during the meeting at any length.
} 
CVM reviewers to task for not asking Aqua Bounty Technologies to re-run flawed studies (Transcript 2010, p.224). Another VMAC member expressed serious reservations about the FDA's CVM's decision to use post-marketing surveillance to complete its safety evaluation. A different VMAC member was dissatisfied with the Aqua Bounty Technologies data and the CVM review on the grounds that it did not provide data about the GE animal's lifespan that would have allowed for the identification of population characteristics (Transcript 2010, p.343).

While the VMAC found the CVM's review of the AquAdvantage salmon NADA deficient, it did not recommend against approval of the GE salmon NADA. Instead, it recommended that the FDA ask for more and better studies from Aqua Bounty Technologies that would provide reliable information about food safety (Transcript 2010, p. 355).

\section{Commentary}

For the purposes of this paper, the FDA's review of Aqua Bounty Technologies' GM salmon is illuminating in two regards. First, while the agency's mission statement claims that its primary aim is to protect public health (US FDA (2012) About FDA ...), in light of its neoliberal leanings, the decision of the CVM reviewers to categorize the GM salmon as safe for human consumption and the environment ${ }^{21}$ strongly suggests that the CVM reviewers (of the FDA) privileged commercial interests over public health. ${ }^{22}$ Even some members of the VMAC -an independent advisory body- seemed to have been influenced by that consideration. One of the VMAC members tellingly argued that her fellow committee members' call for further studies was unacceptable because it would preclude the possibility of the GE fish ever reaching the market (Transcript 2010, p. 356).

There is another reason the review is significant for the purposes of this paper. The VMAC reviewers found multiple studies designed by Aqua Bounty Technologies and the data collected by it to be unreliable for determining the impact of the GM food with respect to safety of food and the environment. While the VMAC's recommendation that the FDA ask the biotechnology company to conduct more and better tests could be read as a sign of Aqua Bounty Technologies' scientific failing, it would be disingenuous to attribute that kind and degree of epistemic incompetence to a biotechnology company that possesses the expertise to develop GM entities. ${ }^{23}$ A more realistic explanation for Aqua Bounty Technologies" "failing" would focus on the normative concerns guiding its safety review of the AquAdvantage salmon. Presumably as a for-profit entity, the biotechnology company's key goal is the rapid market introduction of the GM fish. Its aim in conducting food and environmental studies on the GM salmon was to achieve that end in the most expedient manner. In contrast, the VMAC appeared to be primarily concerned with ensuring the safety of the food supply and the environment (as has been argued above, the same cannot be said for the FDA). Given that their aims coincide partially, it is not surprising that the studies it designed and conducted did not meet the VMAC's standard for good

\footnotetext{
${ }^{21}$ Aqua Bounty Technologies' study design and data do not permit reliable conclusions about those subjects.

${ }^{22}$ While protecting the environment is not one of the FDA's primary goals, in taking on the responsibility of regulating a class of entities that could affect the environment, it incurred that obligation. Whether it has the relevant expertise to address environmental issues is a contested issue (Hoffman 2011).

${ }^{23}$ Aqua Bounty Technologies has other GM fish under development (Unknown. Wall Street Journal (press release) 2013).
} 
research in that they did not provide reliable information for assessing the food and environmental safety of Aqua Bounty Technologies' GM salmon. ${ }^{24}$ However, this crucial normative conflict was not taken up by the CVM reviewers or the VMAC during the meeting. That silence as well as the FDA's failure to acknowledge the influence of neoliberalism on its policies and regulatory review decisions (as evident in the case of the GM salmon) is discussed next. Following that, it is argued that because risk evaluations necessarily entail normative decisions, there should be substantive public engagement in the regulatory process.

\section{An Argument for Democratizing the Regulatory Review of GM foods}

Although the FDA's fundamental mission - protecting public health- is a normative one and, as has been argued above, the agency is influenced by neoliberal values, the regulatory entity insists that its risk evaluations are solely science-based. That is evident, for example, in its response to public comments on the risk assessment of cloned livestock. The agency stated that it "is responsible for protecting the public health by assuring the safety of the nation's food supply ... (and its) mission also includes communication of accurate, science-based information to the public. With respect to food from clones, both of these responsibilities have been fulfilled by conducting the risk assessment and releasing its results, together with the accompanying guidance and risk management plan, to the public. It is not, however, FDA's responsibility to assess potential economic impacts of its regulated products, including foods, being released into commerce" (FDA 2008. FDA's response to public comments ...). The agency also asserted that it had "... not been charged with addressing moral, religious, or ethical issues associated with animal cloning for agricultural purposes.” (FDA 2008. FDA's response to public comments ...). In taking that position, the agency commits itself to a naïve form of positivism, which assumes that scientific activity (such as risk assessments) can be value neutral. ${ }^{25}$ It is usually part and parcel of that stance to reject layperson involvement in decision-making about scientific matters on the grounds that they have mere opinions, rather than knowledge. In that vein, Tait has claimed that the public has "...opinion[s] rather than the best available evidence of potential benefits and risks" (Tait 2009) to which only the scientific community has access. Along the same lines, Sunstein contends that laypersons' opinions are rooted in emotions (Sunstein 2002), rather than reason, and thus, they lack in any epistemic merit. They do not reflect reality in the meaningful way that scientific claims do. Opponents of public participation in decision-making about biotechnologies also believe that the scientific community can be expected to ensure that the products are safe, and market forces can be relied on to provide accurate information about "... whether people want a particular technology" (Tait 2009). Public decision-making about

\footnotetext{
${ }^{24}$ As noted earlier, the FDA permits developers of GM food to design their own safety studies.

${ }^{25}$ It is arguable if the FDA's position can be classified as one with which positivists such as Carl Hempel would be willing to align themselves. The positivists had a fairly complex understanding to the integral role of values in scientific inquiry. For instance, Hempel acknowledged that values played a critical role in context of discovery and crucially determined the questions that were taken up for inquiry (2001, pp. 372-3; 1966, p.16). It is unclear that the FDA's stance is cognizant of that reality. The fact that contextual values may be embedded in background assumptions that mediate the relationship between hypotheses and evidence claims (Longino 1990) is not acknowledged by the agency. (The positivists too failed to recognize that.)
} 
which biotechnology products should be developed (and safety concerns about them) is construed as an unjustified expense and a premature, unwarranted course of action because the public does not have the knowledge "... to decide what products citizens should be allowed to purchase in 10-15 years" (Tait 2009).

These arguments against public engagement in the risk regulation of GM food rest on the following two flawed assumptions:

i. The risk evaluations of biotechnology can and should be a purely scientific endeavor that reveals accurate, value neutral information about the potential risks and benefits from the biotechnology.

ii. The claims of concerns or interests expressed by laypersons are mere opinions that are based on emotion; they do not meaningfully connect with reality.

Below, both these suppositions are shown to be false. After that, it is argued that the current regulatory review process for new GM food should be re-configured so that it is inclusive and unbiased.

The normativity of risk evaluations

Those who oppose the general public's involvement in GM food risk regulation decisionmaking justify their stance on the grounds that risk evaluations are and should be purely scientific endeavors, without any normative components. But that position is flawed. Ethical, political, or other normative considerations pervade all four stages of risk assessment: hazard identification, dose-response modeling, exposure assessment, and risk characterization (National Research Council 1983). As it is impossible to examine all factors, during hazard identification, normative decisions have to be made about the elements that should be construed as risks that ought to be investigated. The decision-makers make normative judgments when they make those choices. For instance, the decision to not conduct whole food studies to determine the effect of consuming a newly developed GM fish on persons with compromised immune systems is a choice that has ethical and political significance.

Choice of research methodology for exposure assessment is also shaped by normative considerations. Investigators do not have unlimited labor or financial resources and their access to appropriate technologies (for example, laboratory equipment) may be limited (Knorr-Cetina 1995, pp.138-9). For example, in the case of an HPV vaccine study, research methodology decisions about study duration, subject selection criteria (including diversity of subjects), and even location of clinical trial sites were governed by social concerns (Intemann \& Melo-Martín 2010). Moreover, in the interest of ensuring that their research is accepted within the scientific community, scientists may use methodologies that are accepted by the majority of their peers and which may have found favor amongst them because of ease of use. For instance, scientists working with laboratory animals have more or less always used only male animals. They believed that females were simply variants of males and including female animals in laboratory experiments was undesirable because "their reproductive cycles and hormone fluctuations would confound the results of delicately calibrated experiments" (Rabin 2014). Scientists remained committed to this research methodology even though considerable evidence had emerged that 
males and females responded differently to various drugs (Rabin 2014). ${ }^{26}$ The decision to use a particular methodology may also be shaped by larger cultural considerations. In the US, risk evaluators tend to use a standardized approach, rather than a particularist one, for collecting emissions data from industrial facilities because the public distrusts experts. The particularist approach provides precise emission data about each manufacturing plant but laypersons find it difficult to compare emissions data from different factories because the data collection rubrics vary from facility to facility (Dunsby 2004). Thus, US risk assessors tend to use the standardized approach as the public is more likely to accept their industrial emissions figures than if they use the particularist methodology (Dunsby 2004). ${ }^{27}$

Risk characterization is also shaped by normative considerations. Policymakers, in consultations with psychologists, economists, and health physicists, attempt to identify the kind and degree of risk that the public might be willing to accept (Schrader-Frechette 1991, 55). Risk-cost-benefit analysis (RCBA) is a method used to characterize risks and is used in decision-making (Schrader-Frechette 1991, p.61). Using RCBA, risk experts convert risks and benefits of products and activities into monetary amounts and decide if the benefits are outweighed by the costs. In doing so, they make ethical or political judgments about the value of human life and the lives of members of different groups (Schrader-Frechette 1991).

Given that risk assessment of GM food (of both the plant and animal variety) necessarily entails normative decisions, in a democracy those who might be affected by those organisms should have the opportunity to decide those issues. That is because the key principle underlying the democratic state is that everyone matters and matters equally (Nielsen 1984). Commitment to that principle, among other things, entails that those with greater wealth should not be able to impinge on the rights or freedoms of others to engage in self-definition even if they have fewer resources than them. Therefore, for instance, everyone get one and only one vote, regardless of his/her wealth.

Opponents of public participation, however, contend that laypersons are unqualified to make decisions about new biotechnologies because they have mere opinions, not knowledge. That claim is challenged in the next section. It is argued that laypersons qua members of informal epistemic communities qualify as epistemic agents. They have knowledge of the values, interests, and beliefs of those communities and if those groups could be affected by a new GM food, they should decide the normative questions involved in the regulatory review of that entity.

Laypersons and epistemic agency

\footnotetext{
${ }^{26}$ In 2014, the National Institute of Health mandated that this practice of exclusion be discontinued (Rabin 2014). ${ }^{27}$ Dunsby relies on Jasanoff's research (1991) to justify his claim about the variation in trust in experts between the US and the UK publics. Jasanoff's Designs on nature (2005) contains detailed case studies that trace the significant events that shaped public attitudes towards experts in the two countries (for a summary of her findings based on the case studies about the differences see p.259). However, they do not flesh out the role played by (allegedly) neutral experts in "encouraging" populations to adopt neoliberal values and practices. While it lies beyond the limited scope of this paper to explore that issue, Tania Murray Li's The will to improve: Governmentality, development, and the practice of politics (2007) and Nikolas Rose's Powers of freedom (1999) usefully illuminate that link.
} 
Laypersons ${ }^{28}$ are able to function as knowers (i.e., epistemic agents) because of their membership in (informal) epistemic communities. There are formal and informal epistemic communities. Academic communities, including scientific societies, belong in the former category. Formal epistemic communities provide their members with ways of understanding the world and so do informal epistemic communities. Different informal epistemic communities differently conceptualize the world (including public affair issues and their solutions) by virtue of their beliefs, interests, and values as well as their historical and current (social, political or legal) relationships with other informal and formal epistemic communities. These informal epistemic communities offer their members ways of understanding and interacting with the human or non-human world; they also construct social reality. ${ }^{29}$ These communities include environmental groups, workers' groups, communities of location (for example neighborhood associations), communities that share a form of life (such as tribes), etc. Laypersons who participate in these communities qualify as epistemic agents because they have crucial knowledge of the values, interests, and concerns of these communities.

In a democracy, the polity has the right to make the normative choices that affect it. Given that the risk regulation of GM food (be it a plant or an animal) involves normative decisions, laypersons (qua epistemic agents) who represent communities that could be affected by a new GM food should have the opportunity to decide the ethical, political or other normative questions related to its risk regulation. To deny those communities the chance to participate in the deliberations and decision-making about new GM foods is to violate the right of the polity to engage in self-governance. ${ }^{30}$

The democratic deliberations approach to GM food risk evaluation proposed here is radically different than the current protocol. In the review process used now, representative of informal epistemic communities are reduced to the level of supplicants, pleading to the FDA to take into consideration their values and interests. They are permitted to offer their comments on the draft safety reports prepared by the agency but it is at the discretion of the FDA to act on them or not. ${ }^{31}$ As mentioned earlier, the agency has been steadfast in its refusal to address any ethical, political, or other normative issues the public may voice on the grounds that its activity and decisions are solely science-based. Thus, during the public meeting about the AquAdvantage salmon, public constituencies, such as environmental organizations, were not able to discuss with the agency their ethical or political concerns about the GM fish, such as whether a GM fish with a significant carbon footprint should be introduced into the market. (The AquAdvantage salmon would need five times more animal protein as food than its non-GM counterpart (Transcript 2010, p.308) and it would have to be transported thousands of miles from the facilities where it is raised to markets around the globe.) Instead, those constituencies had to attempt to engage with

\footnotetext{
${ }^{28}$ While the category of "laypersons" and "scientists" are generally considered to be distinct, it is not the case. "Laypersons" can include scientists, depending on the context. For instance, the holder of a doctorate in a specific scientific subfield, for all intents and purposes, qualifies as a layperson with respect to another scientific discipline or sub-discipline with which she/he has little or no familiarity.

${ }^{29}$ This argument is based on L.H. Nelson's notion of epistemic communities (1993).

${ }^{30}$ It should be noted that this is not an argument for democratizing the regulatory review of pharmaceutical products there are serious problems with the FDA's review of drugs, it lies beyond the scope of this paper to engage with them.

${ }^{31}$ In the US elected representatives cannot be relied on to represent the interests of the average person because the economic elite and corporations have an undue influence on politicians, while average citizens have little influence on public policy (Gilens \& Page 2014).
} 
the FDA by raising questions about the scientific validity of the safety claims made by Aqua Bounty Technologies. That approach was partially successful. The VMAC members, echoing some of those concerns, recommended that the FDA ask Aqua Bounty Technologies for additional and better studies. However, a number of significant ethical and political issues about the introduction of the GM salmon in the market place remained unvoiced and unaddressed, such as, the values that should determine the risk assessment of novel food technologies and which GM food should be developed.

\section{An Inclusive and Unbiased Regulatory Review Process}

As an alternative to the current regulatory review protocol, this paper advocates a democratized regulatory review process for GM food that does not ignore normative questions or marginalize the concerns of informal epistemic communities that could be affected by the novel food product. Within this framework, if a new GM fish, say, a GM trout that has a faster growth rate than its counterpart non-GM trout, were under review, layperson representatives of informal epistemic communities that could be impacted by the fish would be part of the review panel. ${ }^{32}$ Any ethical, political, or other normative questions, such as the values that ought to govern the safety studies conducted on the fish, would have to be decided by the regulatory agency in conjunction with the layperson representatives of those constituencies. The decisions about normative questions would be the result of discussions amongst the participants. During the dialogue, the public constituencies would give to each other reasons for their stance (Bohman 2004, 23). The epistemic justification for the deliberations is that they function as a 'site' where members of society pool their knowledge resources about the significance and impact of the new GM organism on their form of life as well as the values that should inform the risk evaluations conducted on the new GM food. ${ }^{33}$ As part of the deliberations, the constituencies would parse one another's stance and assess the merits of their own position relative to that of others. The discussions about the values and concerns that should govern the risk assessment of the new GM fish would be an opportunity for them to create solutions to public affair problems that drew on the 'knowledge pool.'

This democratic regulatory review process has at least four strengths. First, it would be a crucial corrective to the neoliberal leanings of the regulatory agency because multiple constituencies would decide which values should shape the risk assessment of new GM food. Second, the democratization of the review process would also mean that the agency would have to acknowledge that the risk evaluation process is not value neutral. Third, the revised review protocol is likely to invite public confidence in the FDA's evaluation of new GM food because the regulatory process would be fair (i.e., unbiased) and inclusive. Fourth, the meaningful involvement of multiple public constituencies in the regulatory review process may motivate companies developing new GM foods to engage in substantive and rigorous safety assessments. They would be aware that they would have to satisfy the concerns of a diverse set of public

\footnotetext{
${ }^{32}$ An extended examination of the benefits and limitations of including layperson representatives on risk assessment committees for new GM food lies beyond the modest scope of this paper. But the literature on the impact of inclusion of laypersons in other kinds of committees, such as institutional review boards and hospital ethics committees is likely to provide useful insight.

${ }^{33}$ This idea draws on E. Anderson's work (2006).
} 
constituencies and they could not rely on the regulatory agency's commitment to fostering commercial endeavors to overlook deficiencies in study design and data collection.

It must be acknowledged that this level of public engagement in the regulatory review process may mean that some novel food products will never reach the marketplace if the ethical or political issues raised by its risk assessment cannot be resolved. Thus, there could be epistemic and technological loss with respect to the GM entity under review as well as future products that might have been developed using it. That is a legitimate worry. However, in a democracy, the promise of technological developments, however amazing, cannot be used as an argument to deny those who could be affected by a new product the opportunity to determine the normative issues that are involved in the risk regulation of those entities.

\section{Conclusion}

This paper contributes to the discussion about the democratization of the regulatory review of GM food by giving an original epistemic argument in support of substantive public engagement. The revised review process advocated in this essay would counter the agency's neoliberal bias by giving layperson representatives of public constituencies that could be affected by a new GM food a seat at the regulatory review table.

\section{ACKNOWLEDGMENT}

Research for this paper was funded by a Career Enhancement Grant from the University of Rhode Island's Council for Research. I would also like to thank Jeffrey Burkhardt, the editor, for kindly extending the deadline for submitting the revised paper and the two anonymous reviewers for their comments.

\section{REFERENCES}

Anderson, E. (2006). The epistemology of democracy. Episteme: A journal of social epistemology, 3(1-2): 8-22.

Aqua Bounty Technologies (2010). Environmental assessment for AquAdvantage salmon. http://www.fda.gov/downloads/AdvisoryCommittees/CommitteesMeetingMaterials/VeterinaryM edicineAdvisoryCommittee/UCM224760.pdf

Accessed 12 July 2014.

Bohman, J. (2004). Realizing deliberative democracy as a mode of inquiry: Pragmatism, social facts, and normative theory. Journal of speculative philosophy, 18(1):23-43.

Cattani, D.1., de Liz Oliveira Cavalli, V.L., Heinz Rieg, C.E., Domingues, J.T., Dal-Cim, T., Tasca, C.I., Mena Barreto Silva, F.R., Zamoner, A. (2014). Mechanisms underlying the neurotoxicity induced by glyphosate-based herbicide in immature rat hippocampus: Involvement of glutamate excitotoxicity. Toxicology, 5, 320: 34-45. doi: 10.1016/j.tox.2014.03.001. 
Council on Environmental Quality and Office of Science and Technology Policy (CEQ/OSTP). (2001). CEQ/OSTP assessment: Case studies of environmental regulation for biotechnology. http://www.ostp.gov/html/012201.html. Accessed 11 June 2014.

Domhoff, G.W. (2013). Wealth, income, and power. http://www2.ucsc.edu/whorulesamerica/power/wealth.html. Accessed 11 June 2014.

Dunsby, J. (2004). Measuring environmental health risks: the negotiation of a public right-toknow law. Science, Technology \& Human Values, 29, 269-290.

Federal Food, Drug, and Cosmetic Act (FFDCA, 2004). 21 U.S.C. Section 301-397.

Federal Register 10084. Volume 49. 31 December 1984.

Federal Register 13193. Executive Order 12291. 17 Feb. 1981.

Food and Agriculture Organization (FAO) of the United Nations (2008). The state of world fisheries and aquaculture. Rome.

FoodRisk.org. Biographies.

http://foodrisk.org/irac/events/2003-09-30/bios/. Accessed 11 June 2014.

Gilens, M. and Page, B. (2014). Testing theories of American politics: Elites, interest groups, and average citizens. Perspectives on Politics forthcoming.

http://www.princeton.edu/ mgilens/Gilens\%20homepage\%20materials/Gilens\%20and\%20Page/ Gilens\%20and\%20Page\%202014-Testing\%20Theories\%203-7-14.pdf. Accessed 8 June 2014.

Goldburg, R. (2002). Testimony of Rebecca Goldburg, PhD, Environmental Defense, concerning marine aquaculture, before the US Commission on Ocean Policy. Environmental Defense. Boston, MA.

Guehlstorf, N. P. (2004). The political theories of risk analysis (The international library of environmental, agricultural and food ethics). Springer.

Guia, Y., Fana, X., Wanga, H., Wanga, G., Chena, S. (2012). Glyphosate induced cell death through apoptotic and autophagic mechanisms. Neurotoxicology and Teratology, 34(3), 344349.

Harvey, D. (2005). A brief history of neoliberalism. Oxford UP.

Hempel, C. (2001). Valuation and objectivity in science. The philosophy of Carl G. Hempel. James H. Fetzer (ed.). Oxford UP.

Hempel, C. 1966. Philosophy of natural science. Prentice-Hall. 
Hoffman, E. (2011). GE mosquito release "remains on indefinite hold" -- but for how long? http://www.foe.org/news/blog/2012-05-ge-mosquito-release-remains-on-indefinite-hold. Accessed 11 June 2014.

Intemann, K., \& Melo-Martín, I. (2010). Social values and scientific evidence: The case of the HPV vaccines. Biology and Philosophy 25.2: 203-213.

Jasanoff, S. 2005. Designs on nature: Science and democracy in Europe and the United States. Princeton UP.

Jasanoff, S. (2003). A living legacy: the precautionary ideal in American law. In Precaution, environmental science, and preventive public policy, Joel Tickner (ed.). Washington, DC: Island Press, 227-240.

Jensen, K. (2006). Conflict over risks in food production: A challenge for democracy. Journal of Agricultural and Environmental Ethics, 19(3): 269-283.

Johnson, G. F. (2007). Discursive democracy in the transgenerational context and a precautionary turn in public reasoning. Contemporary Political Theory 6(1): 67-8.

Jones, M.E. (1999). Politically corrected science: The early negotiation of U.S. agricultural biotechnology policy. (Dissertation).

Knorr-Cetina, K. (1995). How superorganisms change: consensus formation and the social ontology of high-energy physics experiments. Social Studies of Science, 25: 119-47.

Levidow, L., Murphy, J., \& Carr, S. (2007). Recasting “'substantial equivalence'? transatlantic governance of gm food. Science, Technology \& Human Values, 32(1), 26-64.

Li, T. M. (2007). The will to improve: Governmentality, development, and the practice of politics. Duke University Press Books.

Longino, H. (1990). Science as social knowledge. Princeton UP

Madsen, K.H. \& Sandøe, P. (2001). Herbicide resistant sugar beets - What is the problem? Journal of Agricultural and Environmental Ethics, 14(2): 161-168.

Logar, N. \& Pollack, L.K. (2005). Transgenic fish: is a new policy framework necessary for a new technology? Environmental Science \& Policy, 8:17-27.

Meghani, Z. and Kuzma, J. (2011). The "revolving door" between regulatory agencies and industry: A

problem that requires reconceptualizing objectivity. Journal of Agricultural and Environmental Ethics, 24(6): 575-599. 
Meghani, Z. (2009). The US' Food and Drug Administration, normativity of risk assessment, GMOs, and American democracy. Journal of Agricultural and Environmental Ethics, 22 (2): 125-39.

Meghani, Z. and de Melo-Martín, I. (2009). The U.S. Food and Drug Administration's evaluation of the safety of animal clones: A failure to recognize the normativity of risk assessment projects. Bulletin of Science, Technology \& Society, 29: 9-17.

Menozzi, D., Mora, C., and Merigo, A. (2012). Genetically modified salmon for dinner?

Transgenic salmon marketing scenarios. AgBioForum 15(3): 276-293 http://www.agbioforum.org/v15n3/v15n3a04-menozzi.pdf.

Accessed 8 June 2014.

Millstone, E., Brunner, E. and Mayer, S. (1999). Beyond 'substantial equivalence.' Nature, 401: $525-526$

Murphy-Lawless, J. (2004). The impact of BSE and FMD on ethics and democratic process. Journal of Agricultural and Environmental Ethics, 17 (4-5): 385-403.

Myhr, A. I. \& Traavik, T. (2003). Sustainable development and Norwegian genetic engineering regulations: Applications, impacts, and challenges. Journal of Agricultural and Environmental Ethics, 16 (4): 317-335.

National Research Council (NRC) (1983). Risk assessment in the federal government. National Academy Press.

National Research Council (NRC) 2002. Animal biotechnology: Identifying science-based concerns. National Research Council, Washington, DC.

Nelson, L. H. (1993). Epistemological Communities. In Feminist epistemologies, Linda Alcoff (ed.). New York: Routledge.

Nielson, K. (1984). Equality and liberty: A defense of radical egalitarianism. Rowman \& Allanheld.

Office of Science, Technology Policy (OSTP). (1986). Coordinated framework for regulation of biotechnology. Federal Register, 51, 23302-23393.

Office of Science \& Technology Policy, Executive Office of The President (2001). Case study no. 1: Growth-enhanced salmon 14.

http://www.whitehouse.gov/files/documents/ostp/Issues/ceq_ostp_study2.pdf. Accessed 11 June 2014. 
Organization for Economic Co-operation and Development (2000). Safety in biotechnology news, 1 (23). http://www.oecd.org/dataoecd/19/38/2412514.pdf. Accessed 11 June 2014.

Peck, J. \& Tickell, A. (2002). Neoliberalizing space. Antipode, 34 (3): 380-404.

Pollack, A. (2010). Genetically altered salmon get closer to the table. NY Times 25 June.

President's Council on Competitiveness (1991). Report on National Biotechnology Policy. http://babel.hathitrust.org/cgi/pt?id=umn.31951003088116i;seq=5;view=1 up;num=iii.

Accessed 17 March 2013.

Rabin, R. C. (2014). Labs are told to start including a neglected variable: Females. NYTimes, May 14. http://www.nytimes.com/2014/05/15/health/nih-tells-researchers-to-end-sex-bias-inearly-studies.html? r=1. Accessed 8 June 2014.

Reagan, R. (1982). Message to the Congress transmitting the annual economic report of the President. http://www.reagan.utexas.edu/archives/speeches/1982/21082a.htm.

Accessed 11 June 2014.

Rollin, B. (1995). The Frankenstein syndrome: Ethical and social issues in the genetic engineering of animals. New York: Cambridge UP.

Rose, N. (1999). Powers of freedom: Reframing political thought. Cambridge UP.

Schrader-Frechette, K. (1991). Risk and rationality: philosophical foundations for populist reforms. University of California Press.

Sheingate, A.D. (2006). Promotion versus precaution: The evolution of biotechnology policy in the United States. British Journal of Political Science 36 (2):243-268.

Sunstein, C. R. (2002). Risk and reason. Cambridge UP.

Tait, J. (2009). Upstream engagement and the governance of science: The shadow of the genetically modified crops experience in Europe. EMBO Rep. 10(S1): S18-S22.

Union of Concerned Scientists (UCS) (2001). Update on genetically engineered fish. www.ucsusa.org/food/upd-gefish.html. Accessed 12 February 2014.

US Congress, House of Representatives, Committee on Science and Technology (1982). US science and technology under budget stress. US Government Printing Office. Washington, DC. December 10, 1981 and February 2, 3, 4, 1982. Hearings. 97/118.

USDA. Dietary guidance: MyPlate and historical food pyramid resources. http://fnic.nal.usda.gov/dietary-guidance/myplate-and-historical-food-pyramid-resources. Accessed 11 June 2014 
US DHHS, USDA, US EPA. Memorandum of understanding among Department of Health and Human Services, FDA, and Department of Agriculture, Animal and Plant Health Inspection Service, Biotechnology Regulation Services and EPA, Office of Chemical Safety and Pollution Prevention, Office of Pesticide Programs. 10-2000-0058-MU 225-11-0001.

http://www.epa.gov/oppbppd1/biopesticides/pips/biotech-mou.pdf

Accessed 11 June 2014.

US EPA. Environmental assessments \& environmental impact statements. http://www.epa.gov/reg3esd1/nepa/eis.htm.

Accessed 11 June 2014.

US FDA. About FDA: Trade secrets.

http://www.fda.gov/downloads/AboutFDA/Transparency/PublicDisclosure/GlossaryofAcronyms andAbbreviations/UCM212053.pdf.

Accessed 16 November 2012.

US FDA. (2012). About FDA: What we do.

http://www.fda.gov/AboutFDA/WhatWeDo/default.htm.

Accessed 11 June 2014.

US FDA. (2103) Advisory Committees: Veterinary Medicine Advisory Committee.

http://www.fda.gov/AdvisoryCommittees/CommitteesMeetingMaterials/VeterinaryMedicineAdv isoryCommittee/default.htm

Accessed 14 June 2014.

US FDA (2012). Briefing packet for AquAdvantage salmon Veterinary Medicine Advisory

Committee.

http://www.fda.gov/downloads/AdvisoryCommittees/CommitteesMeetingMaterials/VeterinaryM edicineAdvisoryCommittee/UCM224762.pdf

Accessed 11 June 2014.

US FDA (2010). Charter of the Veterinary Medicine Advisory Committee.

http://www.fda.gov/AdvisoryCommittees/CommitteesMeetingMaterials/VeterinaryMedicineAdv ${\text { isoryCommittee/ucm } 123835 . \mathrm{htm}^{34}}^{34}$

US FDA (2010). Environmental assessment for AquAdvantage Salmon.

http://www.fda.gov/downloads/AdvisoryCommittees/CommitteesMeetingMaterials/VeterinaryM edicineAdvisoryCommittee/UCM224760.pdf.

Accessed 11 June 2014.

US FDA (1999). Genetically engineered foods: Statement of James H. Maryanski before the Subcommittee on Basic Research House Committee on Science. October 19. http://www.fda.gov/newsevents/testimony/ucm115032.htm

${ }^{34}$ The FDA terminated the VMAC on September 24, 2013 (FDA 2103, Advisory Committees ...), so the website is no longer accessible. 
Accessed 11 June 2014.

US FDA (2009). Guidance for industry regulation of genetically engineered animals containing heritable recombinant DNA constructs final guidance.

http://www.fda.gov/downloads/\%20AnimalVeterinary/GuidanceComplianceEnforcement/\%20\% 20GuidanceforIndustry/UCM113903.pdf

Accessed 11 June 2014.

US FDA. Importation of Active Pharmaceutical Ingredients (APIs) Requirements FD\&C Act 201 $(g) \&(p)$ [21 USC 321 $(g) \&(p)]:$ Definitions; generally (Tab B).

http://www.fda.gov/downloads/AboutFDA/CentersOffices/CDER/ucm118000.pdf

Accessed 11 June 2014.

US FDA (2008). FDA's response to public comment on the animal cloning risk assessment, risk management plan, and guidance for industry (Docket No. 2003N-0573). Available at http://www.fda.gov/AnimalVeterinary/SafetyHealth/AnimalCloning/ucm055491.htm Accessed 11 June 2014.

US FDA (2010). Transcript for the September 20, 2010 Veterinary Medicine Advisory Committee Meeting.

http://www.fda.gov/downloads/AdvisoryCommittees/CommitteesMeetingMaterials/VeterinaryM edicineAdvisoryCommittee/UCM230471.pdf.

Accessed 11 June 2014.

Unknown (2013) AquaBounty cleared to produce salmon eggs in Canada for commercial purposes (Press release). Wall Street Journal. Nov. 25.

http://online.wsj.com/article/PR-CO-20131125-903183.html.

Accessed 14 June 2014.

World Health Organization (2008). Guideline for the conduct of food safety assessment of foods derived from recombinant-DNA animals CAC/GL 68-2008.

http://www.who.int/foodsafety/biotech/codex_taskforce/en/.

Accessed 11 June 2014.

Wynne, B. (1989). Sheep farming after Chernobyl: a case study in communicating scientific information. Environment, 31(2). 